This item was submitted to Loughborough's Research Repository by the author.

Items in Figshare are protected by copyright, with all rights reserved, unless otherwise indicated.

\title{
Scenario-neutral approach to climate change impact studies: application to flood risk
}

PLEASE CITE THE PUBLISHED VERSION

https://doi.org/10.1016/j.jhydrol.2010.06.043

PUBLISHER

(C) Elsevier

VERSION

AM (Accepted Manuscript)

\section{PUBLISHER STATEMENT}

This work is made available according to the conditions of the Creative Commons Attribution-NonCommercialNoDerivatives 4.0 International (CC BY-NC-ND 4.0) licence. Full details of this licence are available at: https://creativecommons.org/licenses/by-nc-nd/4.0/

\section{LICENCE}

CC BY-NC-ND 4.0

\section{REPOSITORY RECORD}

Prudhomme, Christel, Robert L. Wilby, Sue M. Crooks, Alison L. Kay, and Nick S. Reynard. 2019. "Scenarioneutral Approach to Climate Change Impact Studies: Application to Flood Risk". figshare. https://hdl.handle.net/2134/37597. 


\section{Scenario-neutral approach to climate change impact studies: application to flood risk}

Prudhomme $^{1}$, C., Wilby ${ }^{2}$, R.L., Crooks ${ }^{1}$, S., Kay ${ }^{1}$ A. and Reynard ${ }^{1}$, N.S.

${ }^{1}$ Centre for Ecology and Hydrology, Maclean Building, Wallingford, OX10 8BB, UK

${ }^{2}$ Department of Geography, Loughborough University, Leicestershire, UK

Prepared for:

Journal of Hydrology

21 January 2010

Word count:

8802 (including references and figures)

Corresponding author:

Christel Prudhomme

Centre for Ecology and Hydrology

Crowmarsh Gifford

Wallingford

Oxfordshire

OX10 8BB

e-mail: chrp@ceh.ac.uk 


\section{ABSTRACT}

This paper presents a novel framework for undertaking robust climate change impact studies, which can be used for testing the robustness of precautionary climate change allowances used in engineering design. It is illustrated with respect to fluvial flood risk in the UK. The methodology departs from conventional scenario-led impact studies because it is based on sensitivity analyses of catchment responses to a plausible range of climate changes (rather than the time-varying outcome of individual scenarios), making it scenarioneutral. The method involves separating the climate change projections (the hazard) from the catchment responsiveness (the vulnerability) expressed as changes in peak flows. By combining current understanding of likelihood of the climate change hazard with knowledge of the sensitivity of a given catchment, it is possible to evaluate the fraction of climate model projections that would not be accommodated by specified safety margins. This enables rapid appraisal of existing or new precautionary allowances for a set of climate change projections, but also for any new set of climate change projections for example arising from a new generation of climate models as soon as they are available, or when focusing on a different planning time horizon, without the need for undertaking a new climate change impact analysis with the new scenarios. The approach is demonstrated via an assessment of the UK Government's 20\% allowance for climate change applied in two contrasting catchments. In these exemplars, the allowance defends against the majority of sampled climate projections for the 2080s from the IPCC-AR4 GCM and UKCP09 RCM runs but it is still possible to identify a sub-set of regional scenarios that would exceed the $20 \%$ threshold.

\section{KEY WORDS}

Climate change scenario; water policy; impact assessment; flood risk; IPCC-AR4, UKCIP9, UK; GCM; RCM 


\section{INTRODUCTION}

Given the legacy of historic greenhouse gas emissions and the prospect of unavoidable climate change, the case for committing significant financial and technical resources to adaptation is gaining ground (UNDP, 2007; Parry et al., 2009). However, it may be contested that to date more scientific effort is being expended on characterising the uncertainty in climate change projections, than on developing robust adaptation responses to a range of plausible climate outcomes (Wilby and Dessai, 2009). There are varied explanations for the disconnection between information providers and knowledge users but McNie (2007) believes it is due to scientists producing too much of the wrong kind of information. Indeed, when coastal managers in California were asked what they wanted, the answers were clear enough: uncertainty ranges around climate change (impact) projections; distinctions between more or less likely outcomes; a scientific basis for precautionary allowances in engineering design; and basic explanations of the causes of the uncertainty (Tribbia and Moser, 2008). Above all, interviewees wanted climate change scenarios translating into management-relevant variables (e.g., rates of coastal erosion and retreat rather than sea level rise; groundwater recharge and levels rather than rainfall). Such sector-specific and specialist needs are clearly beyond the remit of national climate change scenarios, and require additional levels of post-processing and downscaling of climate risk information.

Projected changes in climate are expected to increase fluvial flood risk across England and Wales (Wilby et al., 2008). Current approaches to incorporating possible changes in peak flows from future climate change is described in project appraisal guidance issued by the UK Government's Department for Environment Food and Rural Affairs (Defra) (see: $\quad$ http://www.defra.gov.uk/environ/fcd/pubs/pagn/climatechangeupdate.pdf). This requires all flood management plans to include, within a sensitivity analysis, an increase of up to $20 \%$ over the next 50 to 100 years. The $20 \%$ allowance is kept constant out to 2115 , unlike some other variables (such as peak rainfall intensity), and is the same across England and Wales, making no allowance for regional variation in climate change or catchment type. At the time of this guidance the underpinning science was not yet available to resolve the spatial distribution of climate change impacts on flood flows with enough confidence to set policy regionally.

We examine the utility of a framework for testing robustness of climate change allowances, by referring to the UK's flood protection standards. First, we set the scene by summarising existing approaches to climate change adaptation under uncertainty. Then we describe the information sources needed to calibrate and validate a continuous river flow simulation model, before applying regional climate change scenarios to a sensitivity analysis 
of the hydrological models. This involved development of a novel technique for capturing key features of a climate model ensemble that acknowledges uncertainties in projected interdecadal and intra-annual climate changes. Resulting distributions of climate change factors, combined with the river flow modelling, enable the construction of sensitivity response surfaces in a scenario-neutral framework, and hence provide evidence with which to assess the likelihood that the Defra flood allowance could be exceeded at specified time-horizons and flood magnitudes. Finally, we outline plans for a more exhaustive analysis of flood risk, and prospects for refining existing design allowances to better reflect regional variations in climate impact.

\section{ADAPTATION DECISION-MAKING UNDER UNCERTAINTY}

Conventional, "top-down" (scenario-led) approaches to climate change adaptation involve three steps. First, scenarios describing future regional climate are derived either directly or indirectly from the output of Coupled Ocean-Atmosphere Global Climate Models (OA/GCM, or GCM hereafter). Examples of the former approach include "delta" or Change Factor (CF) methods (Hay et al., 2000); examples of the latter include downscaling via empirical transfer functions or dynamically using Regional Climate Models (RCMs) (see the review of Fowler et al., 2007). Second, these scenarios are input to impacts models to provide quantitative estimates of future consequences. For example, flood quantiles derived from modelled time series of river flows under future rainfall regimes might be compared with the same quantiles derived from simulated historic (or 'baseline') flow series to define the change in each quantile. Third, adaptation responses are invoked in order to counter anticipated risks or to realise any benefits. For example, expected changes in flood magnitude, for given regions, time periods and emission scenarios might be tabulated for flood engineers as in the case of southwest Germany: based on output from a single climate model (ECHAM4), climate change allowances for floods with 50 -year return period by the 2050 s range between +18 to $+35 \%$ depending on region (Ihringer, 2004).

Although scenario-led impact assessment has dominated thinking on adaptation to date, there are actually very few tangible examples of anticipatory or planned adaptation decisions arising from these assessments. The vast majority of research studies stop at the impact assessment per se. One explanation may be that the 'envelope' of uncertainty expands at each step in the cascade (from emissions, to atmospheric concentrations of greenhouse gases, to climate model sensitivity, etc.) reaching the point where the range of outcomes offered to the decision-maker is simply bewildering (or worse, spans changes of opposite sign). Although characterising climate uncertainty may be scientifically tractable 
through international comparison studies and 'hyper-matrix' experiments involving large ensembles of climate models and downscaling methods (Giorgi et al., 2008), reducing uncertainty will be contingent on progress in climate science (see Hawkins and Sutton, 2009). Furthermore, it is acknowledged that even "probabilistic" projections do not bracket all known uncertainties because their distributions of climate changes are highly conditional upon the experimental design (Dessai and Hulme, 2004; Hall, 2007). With each successive climate scenario release, there is also a danger of perceived redundancy, as earlier scenarios, impact and adaptation studies are disregarded by users (Hulme and Dessai, 2008).

This paper presents a scenario-neutral approach to climate change impact studies, which can be used to test the robustness of adaptation strategies such as safety margins. The proposed framework determines the fraction of climate model scenarios that would be accommodated by a specified safety margin (Figure 1). The framework draws on four main information sources: 1) the climate change allowance or safety margin itself, also known as a "design allowance", "headroom", or "freeboard" for climate change (in this case $+20 \%$ to peak river flows); 2) a mathematical model of the climate-response system (the climateimpact model, in this case fluvial flooding); 3) an ensemble of climate change projections to bound a sensitivity analysis of the impact model in \#2; and; 4) metric(s) to show the likelihood that the safety margin in \#1 is robust to the available sample of climate change projections. A key strength of the framework is that it is open to the emergence of new climate change projections (for example from a new generation of climate models, or using a new emission pathway), to a change in the planning time horizon to focus on (2020s instead of 2080s), or to evolving societal attitudes to risk. When evidence of significant evolution in the climate change projections appear, when a different future time horizon is considered, or where a case can be made on social, economic or environmental grounds, a policy refresh or adjustment to the original safety margin might be triggered easily from and update of the framework without the need of extensive additional climate impact analyses. We demonstrate the approach using an appraisal of design allowances for flood risk in two contrasting UK catchments.

\section{INFORMATION SOURCES}

\section{Rainfall-runoff data}

The approach was evaluated using two test catchments located in contrasting regions of the UK: north west Scotland (Enrick at Mill Tore) and south east England (Roding at Redbridge) (Table 1). The hydrological model used to quantify the climate change response of flood flows is a conceptual lumped rainfall-runoff model requiring daily series of precipitation, 
potential evapotranspiration (PE) and temperature as inputs, alongside observed daily river flow series for calibration. Therefore it is changes to these data series that are required in implementing the framework shown on Figure 1.

Daily river flow and precipitation time series were obtained from the UK National River Flow Archive (NRFA). Daily raingauge data were used to generate catchment-average daily rainfall, using the Triangle Method of Jones (1983). Gridded monthly PE data based on the Penman-Monteith equation (Monteith 1965) were obtained from the UK Meteorological Office Rainfall and Evaporation Calculation System (MORECS) (Thompson et al. 1982; Hough et al. 1997). Gridded time-series of daily minimum and maximum temperature data were also provided by the UK Met Office as part of the suite of latest products from the UK Climate Impact Programme (http://www.ukcip.org.uk/). These data were used to calculate mean daily temperature time-series as the average of the minimum and maximum temperature for a location representative of the centre of the catchment. Altitudes, not available with the temperature data, were taken from the $\mathrm{CEH} 50 \mathrm{~m}$ resolution Institute of Hydrology Digital Terrain Model (IHDTM) developed by Morris and Flavin (1990).

\section{GCM projections}

GCM projections from the Fourth Assessment Report of the Intergovernmental Panel on Climate Change (IPCC-AR4) are now available to the scientific community through a secured Data Distribution Centre internet portal (http://www.ipcc-data.org/). Time series where obtained through the link to the Climate and Environmental Retrieving and Archiving (CERA) portal (http://cera-www.dkrz.de/CERA/index.html). These are representative of the control run (baseline) and runs assuming different emission scenarios (see below). Note that although GCMs are run at sub-hourly time-steps, the majority of climate modelling centres archive data at daily or monthly resolutions. In order to maximise the size of the climate model ensemble used in our analysis, we employ monthly output.

Each climate variable is available in compressed format (NetCDF or GRIB) globally. However, GCMs discriminate between ocean and land via a land-sea mask. Using this information, monthly time series of precipitation and temperature were extracted for the UK from the 17 GCMs listed in Table 2. To avoid any bias due to an ocean grid-box describing the atmosphere over land, only simulations from land-cells were considered, following Vidal and Wade (2008).

The IPCC employs different pathways describing the future evolution of greenhouse gas emissions, depending on assumptions about the social and economic storyline, generally referred to as the 'SRES emission scenarios' (IPCC, 2000). These emissions scenarios were used as inputs for the 17 GCMs to determine the outcome of changes in 
greenhouse gases concentrations observed during the $20^{\text {th }}$ century (control run $20 \mathrm{C} 3 \mathrm{M}$ ), based on three plausible storylines for the future (Table 3).

\section{CHARACTERISING DECADAL CLIMATE CHANGE}

Due to recognised biases, direct use of GCM output in (hydrological) impact assessment is not recommended (Fowler et al., 2007). For this reason, many techniques have been developed to generate synthetic climate series, ranging from simple empirical methods such as climate change factors (e.g., Arnell, 2003), dynamical modelling with Regional Climate Models (RCMs) (e.g., Déqué et al., 2007), empirical downscaling (e.g., Wilby and Fowler, 2009), or statistical weather generators (e.g., Kilsby et al., 2007).

Our approach is based on the so called "change factor (CF)", "delta change" or "perturbation" method using monthly mean precipitation and temperature. This proceeds in three steps. First, a reference climatology must be defined for the site or region of interest. To date, most studies employ 1961-1990 as the baseline (e.g., the global gridded climatology of New et al., 2002). Note however, this particular period does not necessarily represent the full range of variability evident in earlier instrumental records. Furthermore, although World Meteorological Organization (WMO) climate means are conventionally defined using 30-year periods (WMO, 1983), the IPCC-AR4 has been moving towards the use of 20-year reference periods (IPCC, 2007).

Second, absolute or percentage changes in the equivalent variable are calculated for the GCM grid-box closest to the target site using projections for a specified period in the future. For comparability the baseline and future time-slices used to calculate CFs should be the same length. Previous scenario sets, published by UKCIP02 (Hulme et al., 2002), or IPCC (2007), refer to standard periods of 2011-2040 (2020s), 2041-2070 (2050s) and 20712100 (2080s). For example, for temperature an absolute difference of $3^{\circ} \mathrm{C}$ might be inferred by taking the difference in mean temperatures between 1961-1990 and the 2050s. For precipitation, the $\mathrm{CF}$ is the percentage change in the means between the baseline and future time-slice(s).

Third, the change suggested by the GCM (in this case, for temperature $+3^{\circ} \mathrm{C}$ ) is simply added to the reference climatology and the resulting time series is used for impacts modelling. For precipitation, perturbed series are typically derived by scaling the reference series by the monthly CFs.

Without modification, the CF method yields uniform changes to all precipitation intensities (i.e., spanning drizzle to extreme events), and the frequency of wet-days is 
unchanged (i.e., the temporal structure of future climate scenarios is unchanged) (Diaz-Nieto and Wilby, 2005; Kilsby et al., 2007). On the other hand, uncertainties due to GCM and emission scenarios - recognised to be the largest components affecting predictions longer than 20 years from present (Rowell, 2006; Hawkins and Sutton, 2009) - are readily sampled by deriving CFs for as many GCM experiments as possible. Additional uncertainty due to $\mathrm{RCM}$ formulation can also be explored by deriving CFs from RCM experiments driven by the same host GCMs (Déqué et al., 2007). With increasing availability of transient GCM experiments, CFs can also be defined for any future time horizon for which projections exist. This is not yet possible for most RCM projections since these tend to be run for limited time slices (such as the 2080s for the PRUDENCE project, http://prudence.dmi.dk/) unless timescaling methods are applied as in the case of the UKCIP02 scenarios (Hulme et al., 2002). In the following case study, GCM and RCM information was used only for the 2071-2100 (2080s) time horizon.

As noted above, large decadal variability in observed climate means that CFs inferred from time-slices are sensitive to the choice of reference period, as well as the length(s) of the two periods. The definition of the CF, previously considered trivial, does in fact require more rigorous treatment if the range of decadal variability is to be properly sampled. The widespread practice of relying on a single value from the baseline and future, such as the difference between 2071-2100 and 1961-1990, is now recognised to be susceptible to sampling uncertainty (Räisänen and Ruokolainen, 2006; Kendon et al., 2008). As an example of this, Figure 2 and Figure $\mathbf{3}$ show precipitation and temperature CFs respectively for grid boxes located over Scotland and SE England, taken from four GCM projections under SRES A2 emissions. For each month, the box-plots show the distribution of CFs derived from all pairs of continuous 20-year blocks that can be drawn from within the reference (1951-2000) and future (2071-2100) periods. For comparison, the dotted black line shows CFs as defined by the conventional differencing of just two periods, i.e., the percentage change between the mean of 2071-2100 and the mean of 1961-1990. In several instances the two-period mean falls outside the inter-quartile range due to natural variability (e.g., March precipitation changes projected by ECHOG, south cell; November temperature changes projected by HadGEM, north cell). In other words, conventional CFs would not always be representative of the actual distribution of CFs based on exhaustive differencing. Therefore, the following analyses were based on the full range of CFs to better represent uncertainty due to natural variability between periods.

\section{CHARACTERISING INTRA-ANNUAL CLIMATE CHANGE}


In addition to uncertainty due to the reference periods (used for both the baseline and the future), CFs exhibit marked seasonal variation (see Figure 2 and Figure 3). Therefore, climate change impact assessment based on sensitivity to mean annual changes (as in Jones et al., 2006) could overlook important changes in the hydrological cycle. A shift in the rainfall season, or a lengthening of the dry season, could have important consequences for the seasonal distribution of the soil moisture, and in turn, on the capacity for a catchment to absorb rainfall or alternatively, to be saturated and generate larger floods.

Using the same 20-year sampling method as above, CFs for monthly precipitation and temperature were calculated for all IPCC-AR4 available GCM projections (Table 2) and emission scenarios (Table 3) taken from all land cells over the UK. In the majority of cases (not shown), two clear seasonal patterns emerge. For precipitation, large increases are found in winter and reductions to zero changes in summer, with spring and autumn in transition between the two. This is consistent with the expected 'wetter winters, dryer summers' of the UKCIP02 (Hulme et al., 2002) and UKCP09 (Murphy et al., 2009) scenarios. Temperature increases are seen throughout the year but are generally larger in the summer. In some cases, the seasonal structure is less clear due, in part, to large uncertainty in monthly CFs.

Harmonic analysis was applied herein to the monthly CFs to synthesise and smooth the large intra-annual variations using the following expression:

$$
X_{t}=X_{0}+\sum_{i=1}^{N / 2} A_{i} \cos \left(\frac{2 \pi i t}{P}-\Phi_{i}\right)
$$

where $\mathrm{X}_{\mathrm{t}}$ is the value of the series at time $t, X_{0}$ is the arithmetic mean, $A_{i}$ is the amplitude of the harmonics, $\Phi_{i}$ the phases in angles of the corresponding harmonics (in radians), $N$ the number of observations and $P$ the period of observation (Wilks, 2006). In our case, $P$ equals 12 months, and the function is fitted on the monthly median of the CFs derived from the 20-year average incorporating both control and future variability. The type of variation dominating the curve is revealed by the comparative size of the amplitudes $A_{i}$, where a large first harmonic suggests a strong annual variation. The phase angle $\Phi_{i}$ indicates the time of the year of the maximum or minimum of a given harmonic occurs and was converted to months (Kirkyla and Hameed, 1989).

Use of the first two harmonic functions to describe the inter-annual variation of the factor of changes is illustrated in Figure $\mathbf{4}$ and Figure 5. These cases were selected to illustrate how harmonic functions describe both marked and weak seasonal patterns. In the 
case of marked seasonal variations, the strong annual cycle is adequately captured by the first harmonic and the addition of a second harmonic is not necessary (e.g., precipitation changes projected by ECHOG, Figure 4). Representation of a second peak in the CF interannual pattern is improved by the means of a second order harmonic (e.g., temperature changes by CSMK3, Figure 5), but generally the existence of a double cycle is driven by large CF ranges found in some months which can be significantly different from previous and subsequent months. For comparison, the conventional time-slice CFs defined by the difference between the monthly means of 2071-2100 and 1961-1990 are shown as dashed lines in each graph. [We note in passing that some smoothing was applied to the UKCIP02 scenarios to reduce month-to-month variations in CFs (see Hulme et al., 2002)]. In 94\% of the months the first harmonic (i.e. simple sine curve) fits the range of CFs (i.e., falls within the range of CFs described by the whisker-and-box-plots) when fitted to the median of each monthly CF range.

Figure 6 and Figure 7 show histograms of the parameters for harmonic functions produced by combining all GCM results from the same emission scenario. Mean annual change in precipitation varies between more than $\pm 12.5 \%$ (Figure 6 , top row). In Scotland, most of the GCM experiments suggest a mean annual increase of precipitation of more than $2.5 \%$, compared with $\pm 7.5 \%$ for SE England. For the north, around $30 \%$ of the experiments are associated with a strong seasonal pattern (amplitude greater than 20\%), compared with more than $50 \%$ in the south (Figure 6, second row). Precipitation increase is largest in winter for nearly all experiments, regardless of the region (Figure 6, third row) consistent with the changes in winter rainfall reported for the UKCIP02 and PRUDENCE scenarios (see Haylock et al., 2006). The secondary peak is seen to occur primarily in autumn, and for the southern cell, also in winter (Figure 6, bottom row), but is always of low amplitude (Figure 6, fourth row). No strong regional difference in the shape of the harmonic function (mean annual change, seasonality range and phase) emerges from the analysis.

The range in mean annual changes and seasonal pattern for both regions are similar regardless of the emission scenario. This suggests that the decadal variability uncertainty is greater than the emission scenario uncertainty. The most consistent feature can be found for the emission $\mathrm{B} 1$ (hashed bars) where results are not as extreme as for A1B (black) and A2 (white). The majority of experiments suggest mean annual changes in precipitation of no more than $7.5 \%$, with an additional seasonality component of less than $30 \%$ in Scotland and generally less than $30 \%$ in SE England.

Projected temperature changes lie between 2 to $3^{\circ} \mathrm{C}$ in $50 \%$ of GCM experiments in both regions (Figure 7, top row), and between 1 to $4^{\circ} \mathrm{C}$ in $100 \%$ and $98 \%$ of cases in the 
north and the south, respectively. There is a weak seasonal pattern in the warming (the amplitude is less than $1^{\circ} \mathrm{C}$ ), that is marginally str onger in the south (Figure 7, second row), and greater in winter and autumn in the north, and in summer in the south (Figure 7, third row). The effect of the emission scenario on the range of projected mean annual warming is more pronounced in the south, where the modal warming for SRES A2 (white) exceeds $2^{\circ} \mathrm{C}$ (Figure 7, top row right). The effect of the emission scenarios is also discernable in the season of the second order maximum change within the year (i.e., second harmonic) where SRES A1B and A2 generally have the second peak in spring, while for B1, the second peak is most often found in summer in the north, and in no particular season in the south (Figure 7, bottom row). However, these changes are not significant in view of the very small amplitude associated with this secondary peak (less than $0.5^{\circ} \mathrm{C}$, Figure 7 , third row).

For both precipitation and temperature, it emerges from this analysis that the seasonal pattern of changes can be adequately represented by a simple sine curve described by a single-phase harmonic (sine curve), and thus can be summarised by only three parameters: the mean annual change $X_{0}$, the first harmonic amplitude $A_{1}$, and the phase of the first harmonic $\Phi_{1}$.

\section{HYDROLOGICAL MODEL CALIBRATION}

The Probability Distributed Moisture (PDM) model (Moore 1985; 2007) was used for the flood sensitivity testing. This is a lumped conceptual model that treats the whole catchment as a single entity and requires inputs of catchment-average rainfall, PE and temperature with flow data for calibration. The PDM is typical of the relatively simple model structures that nevertheless can be applied effectively across the UK and was developed for continuous simulation of river flow across the complete flow range. The PDM incorporates soil moisture accounting processes, the primary component of non-linearity between rainfall and runoff, and routing procedures for converting effective rainfall into runoff. The version used in this study (Kay et al., 2007) has fewer parameters requiring calibration compared to the full PDM of Moore (1985), which enables to use an automatic calibration routine and limits the problem of equifinality (Beven \& Freer, 2001). For more details about the model and its calibration refer to Crooks et al (2009).

A snow module, adapted from Bell and Moore (1999) was added to the PDM to improve timing between precipitation and runoff for upland catchments. The snow module stores solid precipitation then releases moisture to the hydrological model. The module uses a simple temperature-related snow store and melt rate with eight parameters, including 
threshold temperatures for determining whether precipitation is rain or snow for melting accumulated snow, as well as melt factor and time constants for release of melt from snowpack storage (Crooks et al., 2009). The module was calibrated using temperature and elevation data.

Calibration involved tuning model parameter values to reproduce the characteristics of catchment rainfall-runoff response across the spectrum of hydrological conditions. This was achieved by comparing simulated flows with observed flows, with the difference taken as a measure of model performance (the objective function). Two main objective functions were used here: the efficiency criterion of Nash and Sutcliffe (1970) where a value of 1 indicates a perfect fit, whilst a negative value indicates that the fit is worse than that of the mean value; and a volume error (in \%). Additional objective functions based on the fit of high and low flows were used in the automatic calibration routine. The calibration was deemed satisfactory if the Nash-Sutcliffe value was at least 0.6 for mean daily flows, at least 0.8 for 30-day mean flows, and there was an overall volume error of less than $10 \%$. Four parameters were assigned fixed values or were estimated from catchment properties, while the automatic calibration routine of Calver et al. (2005) was used for the remainder. Finally, observed and modelled hydrographs and flood frequency curves were visually inspected to ensure realism of the fit. The resulting objective functions for the two catchments are provided in Table 1, and further details of the calibration process are reported in Crooks et al. (2009).

\section{CLIMATE SENSITIVITY TESTING}

Having calibrated the PDM, the robustness of the $20 \%$ allowance for flood risk was assessed in each catchment using the IPCC-AR4 ensemble (Table 2) and the framework shown in Figure 1. The sensitivity framework was designed to include the changes currently suggested by IPCC-AR4 GCM (see results from the analysis in Figure 6 and Figure 7), but also to encompass the latest knowledge of future climate change according to the UKCP09 projections (Murphy et al., 2009). The climate change hazard is assumed to be the same within individual GCM grid-cells. The sensitivity analysis exploits the ability of single-phase harmonic function (sine curve) to summarise monthly climate change factors using only three parameters. No significant correlation was found between change in precipitation and temperature patterns (Prudhomme and Reynard, 2009) so the sensitivity analysis can be undertaken for precipitation and temperature independently (Table 4). Because flood regime is less sensitive to temperature than to changes in rainfall regime, the number of temperature scenarios was restricted to eight. However, both the precipitation and 
temperature sensitivity tests sample from a range of scenarios significantly larger than that indicated by the IPCC-AR4 and UKCP09 projections. This is to allow for any significant difference in future projections from the next generation of climate models or new emission pathways to be remain part of the sensitivity domain. Since the changes in precipitation fall in winter for most scenarios, the phase parameter was fixed to mid-winter (January) peak, leaving just two parameters (mean annual change and amplitude of the peak change) to be systematically explored across 525 permutations (Table 4). The eight temperature scenarios have maximum warming (phase) in January and August as well as equal changes throughout the year, selected to reflect the lack of uniformity in the intra-annual pattern of temperature projected changes. A total of 4,200 different climate change factor combinations are thus explored systematically for each catchment.

Monthly CFs were first calculated using the harmonic function formula for each of the 525 precipitation and eight temperature daily series. The temperature-based formula of Oudin et al. (2005) was used to calculate the eight monthly sets of PE changes, based on the Central England Temperature series (http://www.cru.uea.ac.uk/ mikeh/datasets/uk/cet.htm). All sets of monthly CFs were then used to generate synthetic climate time series using the CF method. The calibrated hydrological models were then run with each set of 4,200 synthetic climate time series to produce 4,200 synthetic daily river flow series for each catchment. Finally, the synthetic river flow series were compared with the simulated baseline series to determine 4,200 statistics of flood changes. Here, we use changes in the 20-year return period daily flood peak magnitude (RP20) to illustrate the methodology. Following Prudhomme et al. (2003) a generalised pareto distribution of peak-over-threshold series (Bayliss and Jones, 1993) was fitted independently to the baseline and to the synthetic daily river flow series to estimate changes in the magnitude of RP20 floods.

\section{CHANGES IN FLOOD RISK}

The resulting changes in RP20 are organised in an ensemble of eight sets of results, each ensemble member corresponding to changes in flood peak obtained by running all precipitation changes with one of the eight temperature scenarios. The 525 changes of each ensemble member are displayed in a two-dimensional space bounded by the two variable parameters of the harmonic function, yielding a response surface of the catchment's flood regime to climatic changes (Figure 8). The magnitude of the change in RP20 is represented by a coloured square within the framework, the location of the square depending on the corresponding climate change scenario. The $y$-axis shows the mean annual change $\left(X_{0}\right.$ of 
the harmonic function), hence the bottom half of the diagram represents an overall decrease in annual precipitation (dryer climate) and the top half of the diagram represents an overall increase in precipitation (wetter climate). The x-axis shows change in (the strength of) the seasonality ( $A_{1}$ of the harmonic function) with the left had side representing scenarios with winter and summer changes similar to the mean annual change (small amplitude), while the right hand side represents scenarios where winter and summer changes are very different from the mean annual change (large amplitude), which can be interpreted as amplification of the seasonal cycle. Note that under some scenarios, precipitation increases in all months including in the summer (high mean rainfall change combined with a low seasonal variation, top left corner); for others summer rainfall is reduced to nil (low mean annual change combined with high seasonal variation, leading to factors lower than $-100 \%$ for some summer months, bottom right corner).

Changes in flood peaks characterise the vulnerability of a catchment to prescribed climatic changes. The two exemplar catchments show very different response surfaces to the same climatic drivers. The Enrick at Mill of Tore has a 'neutral' response to climate change, where flood changes (shown as a specific colour in the diagram for a given $\mathrm{x}$ and $\mathrm{y}$ ) are of similar proportion to the peak rainfall change (equal to the monthly change given by the harmonic equation for the month of the phase, $\left.X=X_{0}+A_{1} \cos (0)=X_{0}+A_{1}\right)$. The Roding at Redbridge shows changes in flood peak that are proportionally smaller than the peak rainfall changes, except when rainfall increases all year where changes in flood peak are proportionally greater than winter rainfall changes (top left corner). This means that, except for very wet "scenarios", the catchment generally dampens the signal of change. Note that more "scenarios" generate an actual decrease in flood peak magnitude for the Roding than for the Enrick (grey areas in the bottom left part). Note also that due to the temperature "scenario" (here Medium August scenario of Table 4), a nil change in rainfall leads to a decrease in flood peak as losses in PE increase. Water balance, antecedent catchment conditions, natural variability of the climate and frequency of baseline floods, could all influence the responses of different catchments to climatic changes. It is beyond the scope of this paper to investigate such factors in detail, and further research is needed to identify the variety of responses of UK catchments' flood regime to climatic changes, then to attribute the responses to variations in the physical properties of the catchments.

Once the vulnerability of a catchment has been characterised by these response surfaces, the climate hazard suggested by available climate models can be displayed directly onto the same axes. By combining projections from different model resolutions and structures, different economic pathways and emission scenarios, all of which are plausible, 
the uncertainty domain of the projections can be shown on the sensitivity domain of the catchments. Such a comparison enables rapid appraisal of the efficacy of a given climate change allowance. Taking the example of the UK Government's allowance of $20 \%$ increase in flood peak, we considered projections for the 2080s from 46 IPCC-AR4 GCM runs summarising three emission scenarios (47 for Enrick) covering the catchments and $11 \mathrm{RCM}$ runs used to derive the UKCP09 scenarios (the UK Met Office Hadley Centre Regional Model Perturbed Physics Ensemble simulations HadRM3-PPE, summarising parameterisation uncertainty, Murphy et al., 2007). This reveals that by the 2080s for the Roding, only one (GCM) scenario is associated with an increase of more than $20 \%$ of the 20 -year return flood peak, equivalent to $1.7 \%$ of all scenarios exceeding the current allowance and $2.1 \%$ of the GCM scenarios. In comparison, the same $20 \%$ allowance is exceeded by $8.4 \%$ of all projections (10.9\% of the GCMs) for the Enrick. For these two examples, the HadRM3-PPE projections all suggest changes lower than the $20 \%$ threshold, while for some GCMs, this threshold is clearly exceeded. Note also that the difference in the position of the dots on the response surfaces for the two catchments reflects regional variations in the projected climate hazard.

The methodology and graphical representation of the climate change hazard highlights the uncertainty in climate change projections, revealed by the cloud of dots on the surface responses (Figure 8). This underlines the importance of multi-scenario analysis, including probabilistic assessments. Probabilistic projections such as UKCP09 (Murphy et al., 2009) could be examined using the same framework with a view to testing design allowances. This could be a very powerful tool if implemented nationally, and provide evidence of the robustness (or otherwise) of existing safety margins for climate change. In addition, the versatility of the framework allows any new projection to be evaluated against the same response surface (assuming that the underlying catchment properties remain unchanged). Note that in our example, the climate change projections are all assumed to peak in January so that they can be displayed using the same axes as the response surface. While this assumption may be valid for the UK, the form of the harmonic would clearly be region-specific.

\section{DISCUSSION}

The approach developed here departs from conventional 'top-down' impact studies and was designed to meet the need for a more robust and exhaustive evaluation of precautionary allowances for engineering design in the context of climate change. Based on a sensitivity analysis, catchment responses to changes in climate are determined using a scenario- 
neutral framework. The method involves separating climate change risks (the hazard) from catchment responsiveness (the vulnerability), in this case, expressed as changes in peak flows. By combining knowledge of the likelihood of the hazard (for example through probabilistic future projections, or projections from multiple climate models) with knowledge of the sensitivity of a given catchment, it is possible to provide probabilistic assessments of changes (here in flood peaks) but also to evaluate the fraction of climate model projections that would not be accommodated by specified safety margins. This enables rapid appraisal of precautionary allowances that might arise from cost-benefit analyses and/or policy refresh in response to changing societal attitudes to risk. The approach was demonstrated via an assessment of the UK Government's 20\% allowance for climate change applied in two contrasting catchments. These case studies suggest that the allowance defends against the majority of climate projections sampled. However, it is still possible to identify a sub-set of regional scenarios that would exceed the $20 \%$ threshold.

Our methodology uses a scenario-independent approach to systematically evaluate potential climate change impacts in a way that is meaningful to water managers, stakeholders and policy makers. The approach is versatile in that different response surfaces can be produced for different decision-relevant metrics - in this case changing flood peaks. However, further research is needed to evaluate the implications of some of the assumptions that had to be made for the framework to be practicable. These include: the use of CF method to generate scenarios as opposed to other, more sophisticated downscaling techniques; the use of a harmonic function to smooth monthly CFs; and the assumption that all rainfall changes peak in January in Great Britain. The method is being applied to a much large number of catchments representing a range of characteristics across the UK. The resulting [flood] response surfaces are being grouped into sets with common features (Reynard et al., 2009). Such large, multi-catchment, multi-scenario climate change impact analysis will enable a more thorough appraisal of the $20 \%$ climate change allowance. Following the release of UKCIP09, the latest advances in climate change modelling could readily be incorporated in any policy refresh. One of the outstanding questions is whether a blanket allowance for the whole of England and Wales is still appropriate, or if a regionalised approach (either by administrative district or by catchment type) would be preferable.

The sensitivity framework was specifically designed for evaluating changes in river flood flows but it is readily applied to any sector where changes in the climate can be assessed independently to any other changes through mathematical modelling of impacts. Additional levels of complexity could also be implemented, such as for example testing the impact (on its own or combined with climatic change) of river abstraction on low flows, or 
evaluating the effect of different adaptation measures (Wilby et al., 2006). If particular operational thresholds are known to have significance to the tested system (for example water temperature above $\mathrm{T}$ degrees could kill fish species $\mathrm{S}$ ), the probability of exceedence can be easily evaluated, and if possible, adaptation measures tested. Furthermore, the analytical framework could be used to explore the dynamics of the relationships between climate change impact and non-climatic factors, for example flood response and changed catchment properties.

\section{Acknowledgements}

The authors thank the international modelling groups for providing their data for analysis, the Program for Climate Model Diagnosis and Inter-comparison (PCMDI) and the IPCC-Data Distribution Centre for collecting and archiving the data. The work was co-funded by the Environment Agency for England and Wales, the UK Department for Food and Rural Affairs (Defra) and the Natural Environment Research Council (NERC) which are gratefully acknowledged. Also acknowledged for their collaboration: Karl Hardy and Ella Thomason (Defra), Bill Donovan (EA). The views expressed in this paper are those of the authors and do not necessarily reflect the position held by any of the funding agencies. 


\section{References}

Arnell, N. W. 2003. Relative effects of multi-decadal climatic variability and changes in the mean and variability of climate due to global warming: future streamflows in Britain. Journal of Hydrology, 270,19-213.

Bayliss, A.C. and Jones, R.C., 1993. Peaks-over-threshold flood database: summary statistics and seasonality. IH Report, 121. Institute of Hydrology, Wallingford, 61 pp.

Beven, K. and Freer, J., 2001. Equifinality, data assimilation, and uncertainty estimation in mechanistic modelling of complex environmental systems using the GLUE methodology. Journal of Hydrology, 249(1-4): 11-29.

Crooks, S.M., Kay, A.L. and Reynard, N.S. (2009). Regionalised impacts of climate change on flood flows: hydrological models, catchments and calibration. Report to Department for Environment, Food and Rural Affairs, FD2020 project milestone, CEH Wallingford, 59pp.

Déqué, M., Rowell, D., Lüthi, D., Giorgi, F., Christensen, J., Rockel, B., Jacob, D., Kjellström, E., de Castro, M. and van den Hurk, B. 2007. An intercomparison of regional climate simulations for Europe: assessing uncertainties in model projections. Climatic Change, 81, 53-70.

Dessai, S. and Hulme, M. 2004. Does climate policy need probabilities? Climate Policy 4, 107-128.

Diaz-Nieto, J. and Wilby, R.L. 2005. A comparison of statistical downscaling and climate change factor methods: impacts on low flows in the River Thames, United Kingdom. Climatic Change, 69, 245-268.

Fowler, H.J., Blenkinsop, S. and Tebaldi, C. 2007. Linking climate change modelling to impact studies: recent advances in downscaling techniques for hydrological modelling. International Journal of Climatology, 27, 1547-1578.

Giorgi, F., Diffenbaugh, N.S., Gao, X.J., Coppola, E., Dash, S.K., Frumento, O., Rauscher, S.A., Remedio, A., Seidou Sanda, I., Steiner, A., Sylla, B. and Zakey, A.S. 2008. The regional climate change hyper-matrix framework. Eos, 89, 445-446.

Hall, J. 2007. Probabilistic climate scenarios may misrepresent uncertainty and lead to bad adaptation decisions. Hydrological Processes, 21, 1127-1129.

Hallegatte, S. 2009. Strategies to adapt to an uncertain climate change. Global Environmental Change, 19, 240-247.

Hawkins, E. and Sutton, R. 2009. The potential to narrow uncertainty in regional climate predictions. Bulletin of the American Meteorological Society, early online release, doi:10.1175/2009BAMS2607.1.

Hay, L.E., Wilby, R.L. and Leavesley, G.H. 2000. A comparison of delta change and downscaled GCM scenarios for three mountainous basins in the United States. Journal of the American Water Resources Association, 36, 387-397.

Hulme, M. and Dessai, S. 2008a. Negotiating future climates for public policy: a critical assessment of the development of climate scenarios for the UK. Environmental Science and Policy, 11, 54-70.

Ihringer, J. 2004. Ergebnisse von Klimaszenarien und Hochwasserstatistik. KLIWA Bericht 4, 2. KLIWA Symposium, Würzburg, München.

IPCC, 2000. Special report on emissions scenarios (SRES): A special report of Working Group III of the Intergovernmental Panel on Climate Change, Cambridge University Press, Cambridge. 
IPCC, 2007. Climate Change 2007: The physical science basis. Contribution of Working Group I to the fourth assessment report of the Intergovernmental Panel on Climate Change, Cambridge University Press, Cambridge and New York, Cambridge.

Jones, S.B., 1983. The estimation of catchment average point rainfall profiles, Institute of Hydrology, Wallingford.

Jones, R.N., Chiew, F.H.S., Boughton, W.C. and Zhang, L., 2006. Estimating the sensitivity of mean annual runoff to climate change using selected hydrological models. Advances in Water Resources, 29(10): 1419-1429

Kay, A.L., Jones, D.A., Crooks, S.M., Kjeldsen, T.R. and Fung, C.F., 2007. An investigation of site-similarity approaches to generalisation of a rainfall-runoff model. Hydrology and Earth System Sciences, 11: 500-515

Kendon, E.J., Rowell, D.P., Jones, R.G. and Buonomo, E. 2008. Robustness of future changes in local precipitation extremes. Journal of Climate, 21, 4280-4297.

Kilsby, C.G., Jones, P.D., Burton, A., Ford, A.C., Fowler, H.J., Harpham, C., James, P., Smith, A. and Wilby, R.L. 2007. A daily weather generator for use in climate change studies. Environmental Modelling and Software, 22, 1705-1719.

Kirkyla, K.I. and Hameed, S., 1989. Harmonic Analysis of the Seasonal Cycle in Precipitation over the United States: A Comparison between Observations and a General Circulation Model. Journal of Climate, 2(12): 1463-1475

Lempert, R., Nakicenovic, N., Sarewitz, D. and Schlesinger, M. 2004. Characterizing climate-change uncertainties for decision-makers. Climatic Change, 65, 1-9.

McNie, E.C. 2007. Reconciling the supply of scientific information with user demands: an analysis of the problem and review of the literature. Environmental Science Policy, 10, 17-38.

Murphy, J.M., Booth, B. B. B., Collins, M., Harris, G. R., Sexton, D. M. H., Webb, M. J., 2007. A methodology for probabilistic predictions of regional climate change from perturbed physics ensembles. Philosophical Transactions of the Royal Society A: Mathematical, Physical and Engineering Sciences, 365(1857): 1993-2028.

Murphy, J. M., Sexton, D. M. H., Jenkins, G. J., Booth, B. B. B., Brown, C. C., Clark, R. T., Collins, M., Harris, G. R., Kendon, E. J., Betts, R. A., Brown, S. J., Humphrey, K. A., McCarthy, M. P., McDonald, R. E., Stephens, A., Wallace, C., Warren, R., Wilby, R., Wood, R. A. 2009. UK Climate Projections Science Report: Climate change projections. Met Office Hadley Centre, Exeter.

Oudin, L., Hervieu, F., Michel, C. Perrin, C. Andreassian, V. Anctil, F., Loumagne, C., 2005. Which potential evapotranspiration input for a lumped rainfall-runoff model?: Part 2-Towards a simple and efficient potential evapotranspiration model for rainfall-runoff modelling. Journal of Hydrology, 303(1-4): 290-306.

Parry, M., Lowe, J. and Hanson, C. 2009. Overshoot, adapt and recover. Nature, 485, 11021103.

Prudhomme, C., Jakob, D. and Svensson, C., 2003. Uncertainty and climate change impact on the flood regime of small UK catchments. Journal of Hydrology, 277(1-2): 1-23.

Prudhomme, C. and Reynard, N.S. (2009). Regionalised impacts of climate change on flood flows: rationale for definition of climate change scenarios and sensitivity framework. Report to Department for Environment, Food and Rural Affairs, FD2020 project milestone, CEH Wallingford, 31pp.

Räisänen J. and Ruokolainen, L. 2006. Probabilistic forecasts of near-term climate change 
based on a resampling ensemble technique. Tellus, 58A, 461-472.

Rowell, D.P. 2006. A demonstration of the uncertainty in projections of UK climate change resulting from regional model formulation. Climatic Change, 79, 243-257

Tribbia, J. and Moser, S.C. 2008. More than information: what coastal managers need to plan for climate change. Environmental Science Policy, 11, 315-328.

United Nations Development Programme (UNDP), 2007. Human Development Report 2007/2008. Fighting climate change: Human solidarity in a divided world.

Vidal, J-P and Wade, S.D. 2008. Multimodel projections of catchment-scale precipitation regime. Journal of Hydrology, 353, 143-158.

Wilby, R.L. and Dessai, S. 2009. Robust adaptation to climate change. Weather, in press.

Wilby, R.L. and Fowler, H.J. 2009. Regional climate downscaling. In: Fung, F. and Lopez, A. (Eds.) Climate change and water resource modelling. Blackwell Publishing, Oxford.

Wilby, R.L., Whitehead, P.G., Wade, A.J., Butterfield, D., Davis, R. and Watts, G. 2006. Integrated modeling of climate change impacts on the water resources and quality in a lowland catchment: River Kennet, UK. Journal of Hydrology, 330, 204-220. 
Table 1. Test study catchments main characteristics and calibration objective functions. SAAR $_{61-90}$ : Standard Annual Average Rainfall for the period 1961-1990; BFI: Base Flow Index

\begin{tabular}{|c|c|c|c|c|c|c|c|c|c|c|c|c|}
\hline $\begin{array}{l}\text { Catchment } \\
\text { Number }\end{array}$ & River & $\begin{array}{l}\text { Gauging } \\
\text { station }\end{array}$ & $\begin{array}{l}\text { Longitude } \\
\text { Gauging } \\
\text { station }\end{array}$ & $\begin{array}{l}\text { Latitude } \\
\text { Gauging } \\
\text { station }\end{array}$ & $\begin{array}{l}\text { Catchment } \\
\text { Area }\left(\mathrm{km}^{2}\right)\end{array}$ & $\begin{array}{l}\text { SAAR }_{61-90} \\
(\mathrm{~mm})\end{array}$ & $\mathrm{BFI}$ & $\begin{array}{l}\text { Start } \\
\text { date }\end{array}$ & $\begin{array}{l}\text { End } \\
\text { date }\end{array}$ & $\begin{array}{c}\text { N\&S } \\
\text { (1-day) }\end{array}$ & $\begin{array}{c}\text { N\&S } \\
\text { (30-day) }\end{array}$ & $\begin{array}{l}\text { Volume } \\
\text { error (\%) }\end{array}$ \\
\hline 06008 & Enrick & Mill of Tore & $4.58 \mathrm{~W}$ & $57.33 \mathrm{~N}$ & 105.9 & 1294 & 0.32 & $1 / 1 / 1979$ & $31 / 12 / 2001$ & 0.66 & 0.93 & 2.4 \\
\hline 37001 & Roding & Redbridge & $0.04 \mathrm{E}$ & $51.58 \mathrm{~N}$ & 303.3 & 606 & 0.39 & 1/1/1961 & $31 / 12 / 2001$ & 0.62 & 0.92 & -3.6 \\
\hline
\end{tabular}


Table 2. Global Climate Models (GCM) used in this study. For more details, see http://wwwpcmdi.Ilnl.gov. GCM grid-boxes with less than $50 \%$ land were excluded. No re-gridding was performed.

\begin{tabular}{|c|c|c|c|c|c|c|}
\hline \multirow[t]{2}{*}{ Model } & \multirow{2}{*}{$\begin{array}{l}\text { CERA } \\
\text { Acronym }\end{array}$} & \multirow[t]{2}{*}{ Modelling Group } & \multirow[t]{2}{*}{ Country } & \multicolumn{3}{|c|}{ Spatial Resolution } \\
\hline & & & & $\begin{array}{l}\text { Mesh (Lon } \\
\text { x Lat) }\end{array}$ & $\begin{array}{l}\sim \text { km over } \\
\text { UK }\end{array}$ & $\begin{array}{l}\text { \# UK } \\
\text { land } \\
\text { cells }\end{array}$ \\
\hline $\begin{array}{l}\text { BCCR- } \\
\text { BCM2.0 }\end{array}$ & BCM2 & Bjerknes Centre for Climate Research & Norway & $\begin{array}{l}\text { Gaussian - } \\
128 \times 64\end{array}$ & $280 \times 280$ & 5 \\
\hline CCSM3 & NCCCSM & $\begin{array}{l}\text { National Centre for Atmospheric } \\
\text { Research }\end{array}$ & USA & $\begin{array}{l}\text { Gaussian - } \\
256 \times 128\end{array}$ & $140 \times 140$ & 15 \\
\hline $\begin{array}{l}\text { CGCM3.1 } \\
(\mathrm{T} 47)\end{array}$ & CGMR & $\begin{array}{l}\text { Canadian Centre for Climate Modelling } \\
\& \text { Analysis }\end{array}$ & Canada & $\begin{array}{l}\text { Gaussian - } \\
96 \times 48\end{array}$ & $375 \times 375$ & 4 \\
\hline CNRM-CM3 & CNCM3 & $\begin{array}{l}\text { Météo-France / Centre National de } \\
\text { Recherches Météorologiques }\end{array}$ & France & $\begin{array}{l}\text { Gaussian - } \\
128 \times 64\end{array}$ & $280 \times 280$ & 4 \\
\hline $\begin{array}{l}\text { CSIRO- } \\
\text { Mk3.0 }\end{array}$ & CSMK3 & CSIRO Atmospheric Research & Australia & $\begin{array}{l}\text { Gaussian - } \\
192 \times 96\end{array}$ & $190 \times 220$ & 10 \\
\hline $\begin{array}{l}\text { ECHAM5/ } \\
\text { MPI-OM }\end{array}$ & MPEH5 & Max Planck Institute for Meteorology & Germany & $\begin{array}{l}\text { Gaussian - } \\
192 \times 96\end{array}$ & $190 \times 220$ & 10 \\
\hline $\mathrm{ECHO}-\mathrm{G}$ & $\mathrm{ECHOG}$ & $\begin{array}{l}\text { Meteorological Institute of the } \\
\text { University of Bonn, KMA } \\
\text { meteorological inst., and M \& D group }\end{array}$ & $\begin{array}{l}\text { Germany / } \\
\text { Korea }\end{array}$ & $\begin{array}{l}\text { Gaussian - } \\
96 \times 48\end{array}$ & $375 \times 375$ & 3 \\
\hline $\begin{array}{l}\text { GFDL- } \\
\text { CM2.0 }\end{array}$ & GFCM20 & $\begin{array}{l}\text { Geophysical Fluid Dynamics } \\
\text { Laboratory }\end{array}$ & USA & $\begin{array}{l}\text { Regular - } \\
144 \times 90\end{array}$ & $250 \times 200$ & 8 \\
\hline $\begin{array}{l}\text { GFDL- } \\
\text { CM2.1 }\end{array}$ & GFCM21 & $\begin{array}{l}\text { Geophysical Fluid Dynamics } \\
\text { Laboratory }\end{array}$ & USA & $\begin{array}{l}\text { Regular - } \\
144 \times 90\end{array}$ & $250 \times 200$ & 7 \\
\hline GISS-ER & GIER & $\begin{array}{l}\text { NASA / Goddard Institute for Space } \\
\text { Studies }\end{array}$ & USA & $\begin{array}{l}\text { Regular }-72 \\
\text { x } 46\end{array}$ & $500 \times 390$ & 1 \\
\hline INM-CM3.0 & INCM3 & Institute for Numerical Mathematics & Russia & $\begin{array}{l}\text { Regular }-72 \\
\times 45\end{array}$ & $500 \times 400$ & 3 \\
\hline IPSL-CM4 & IPCM4 & Institut Pierre Simon Laplace & France & $\begin{array}{l}\text { Regular - } 96 \\
\times 72\end{array}$ & $375 \times 250$ & 4 \\
\hline $\begin{array}{l}\text { MIROC3.2 } \\
\text { (medres) }\end{array}$ & MIMR & $\begin{array}{l}\text { National Institute for Environmental } \\
\text { Studies, and Frontier Research Centre } \\
\text { for Global Change }\end{array}$ & Japan & $\begin{array}{l}\text { Gaussian - } \\
128 \times 64\end{array}$ & $280 \times 280$ & 3 \\
\hline $\begin{array}{l}\text { MRI- } \\
\text { CGCM2.3.2 }\end{array}$ & MRCGCM & Meteorological Research Institute & Japan & $\begin{array}{l}\text { Gaussian - } \\
128 \times 64\end{array}$ & $280 \times 280$ & 5 \\
\hline PCM & NCPCM & $\begin{array}{l}\text { National Centre for Atmospheric } \\
\text { Research }\end{array}$ & USA & $\begin{array}{l}\text { Gaussian - } \\
128 \times 64\end{array}$ & $280 \times 280$ & 2 \\
\hline $\begin{array}{l}\text { UKMO- } \\
\text { HadCM3 }\end{array}$ & HADCM3 & UK Met. Office & UK & $\begin{array}{l}\text { Regular }-96 \\
x 73\end{array}$ & $375 \times 250$ & 4 \\
\hline $\begin{array}{l}\text { UKMO- } \\
\text { HadGEM1 }\end{array}$ & HADGEM & UK Met. Office & UK & $\begin{array}{l}\text { Regular - } \\
192 \times 145\end{array}$ & $190 \times 125$ & 14 \\
\hline
\end{tabular}


Table 3. Greenhouse gas emissions scenarios considered in the analysis (IPCC, 2000).

Emission Detail N N

scenario

20C3M Climate of the $20^{\text {th }}$ Century experiment. Generally runs from $\sim 1850$ to present. Control run for SRES emission scenarios A1, A2 and B1 experiments

SRES Future world of very rapid economic growth, global population that peaks in mid-century and

A1B declines thereafter, and the rapid introduction of new and more efficient technologies. SRES A1B assumes a balance across all sources of technology (fossil intensive and non-fossil energy source). Experiments run from conditions from the end of 20C3M until 2100, then with fixed CO2 levels to $720 \mathrm{ppm}$ and continue to run to 2200

SRES A2 Very heterogeneous world. The underlying theme is self-reliance and preservation of local identities, with continuously increasing of global population. Technological changes are slower and more fragmented that in other storylines. Experiments use the end of the 20C3M experiment as their initial condition.

SRES B1 Convergent world with the same population projection as $\mathrm{A} 1$, but with rapid changes in economic structures towards a service and information economy, with reductions in material intensity, and the introduction of clean and resource-efficient technologies. The emphasis is on global solutions to economic, social and environmental sustainability, including improved equity but without additional climate initiatives. Experiments run from conditions from the end of 20C3M until 2100, then with fixed CO2 levels to $550 \mathrm{ppm}$ and continue to run to 2200 
Table 4. Sensitivity framework for precipitation and temperature

\begin{tabular}{|c|c|c|c|c|}
\hline & 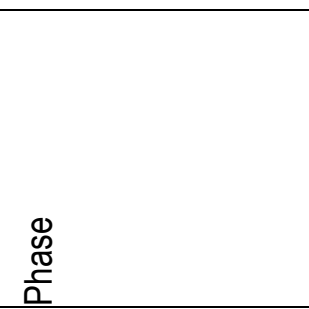 & 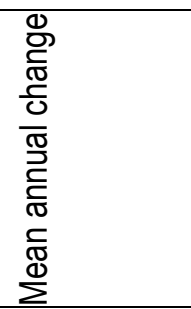 & 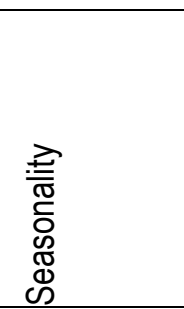 & 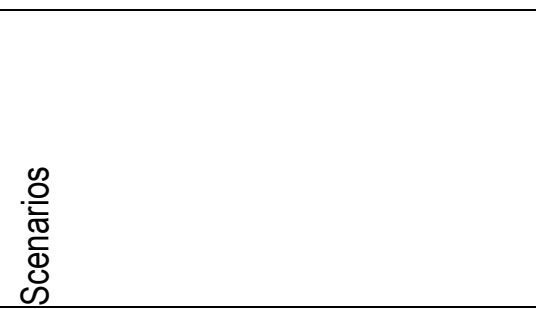 \\
\hline Precipitation & January & $-40 \%$ to $60 \%$ & 0 to $+120 \%$ & $\begin{array}{l}\text { All combinations by increments of } 5 \% \\
\text { Total: } 525 \text { scenarios }\end{array}$ \\
\hline \multirow[t]{2}{*}{ Temperature } & $\begin{array}{l}\text { January and August } \\
\text { None }\end{array}$ & $\begin{array}{l}1.5^{\circ} \\
2.5^{\circ} \\
4.5^{\circ}\end{array}$ & $\begin{array}{l}1.2^{\circ} \\
1.8^{\circ} \\
1.6^{\circ}\end{array}$ & $\begin{array}{l}\text { Low-Jan and Low-Aug } \\
\text { Medium-Jan and Medium-Aug } \\
\text { High-Jan and High-Aug }\end{array}$ \\
\hline & & $0.5^{\circ} ; 4.5^{\circ}$ & $0^{\circ}$ & $\begin{array}{l}\text { Low-/High-Non-Seasonal (NS) } \\
\text { Total: } 8 \text { scenarios }\end{array}$ \\
\hline
\end{tabular}


Figure 1. Climate change impact study scenario-neutral conceptual framework for testing the robustness of climate change allowances. The activities shown in grey boxes were not addressed by the present study.

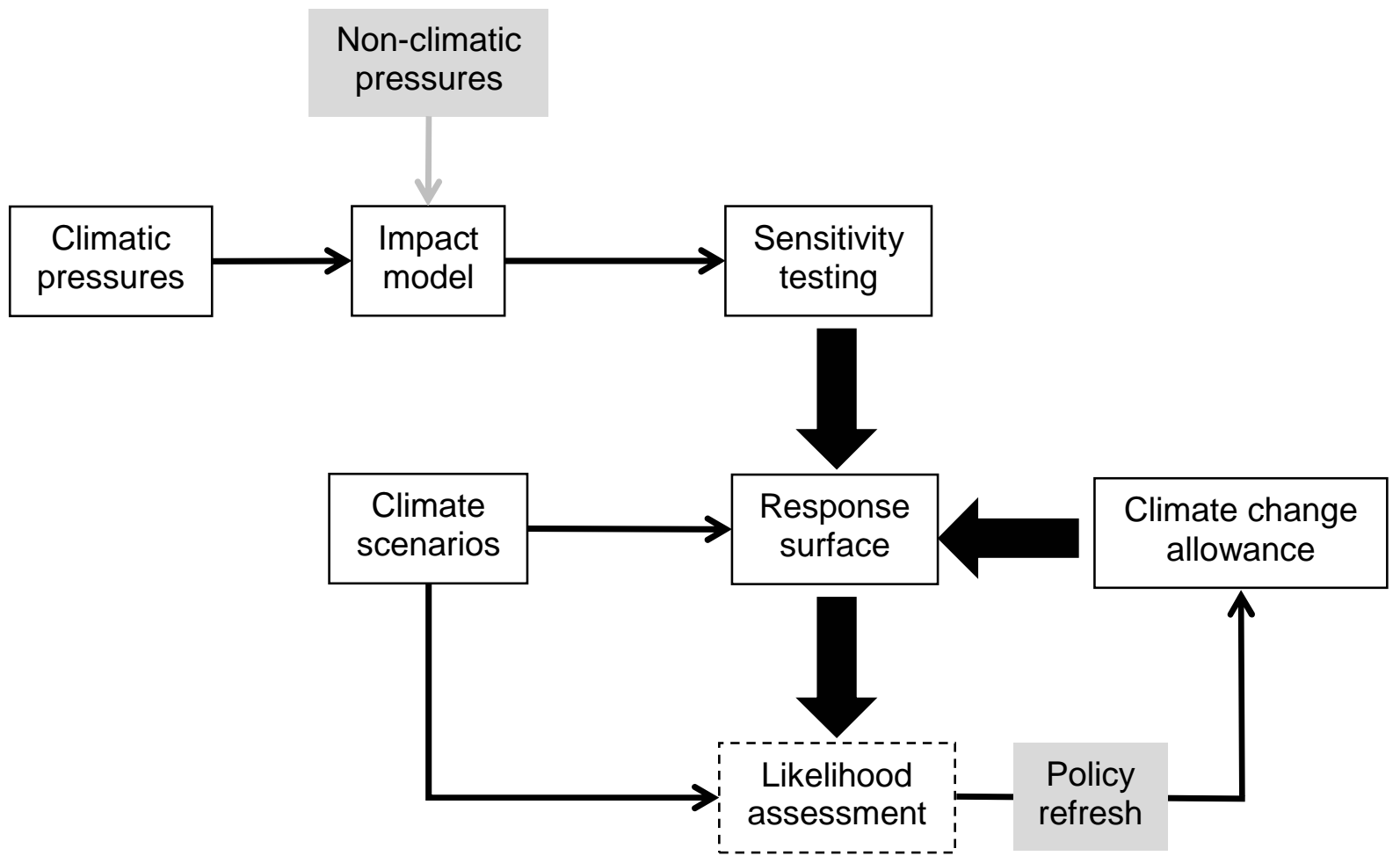


Figure 2. Selected examples of change factors for precipitation over Scotland (top row) and SE England (bottom row) based on 20-year average for the 2080s: [2071-2100] compared to [1961-1990] (horizontal dashed back line) or with respect to all 20-year averages sampled from blocks within [1951-2000] (box plots: first and third quartiles: rectangle; median: thick black line; 1.5 times inter-quartile range: whiskers; outliers: circles).

MPEH5 - 2080s changes - SRA2

HADGEM - 2080s changes - SRA2
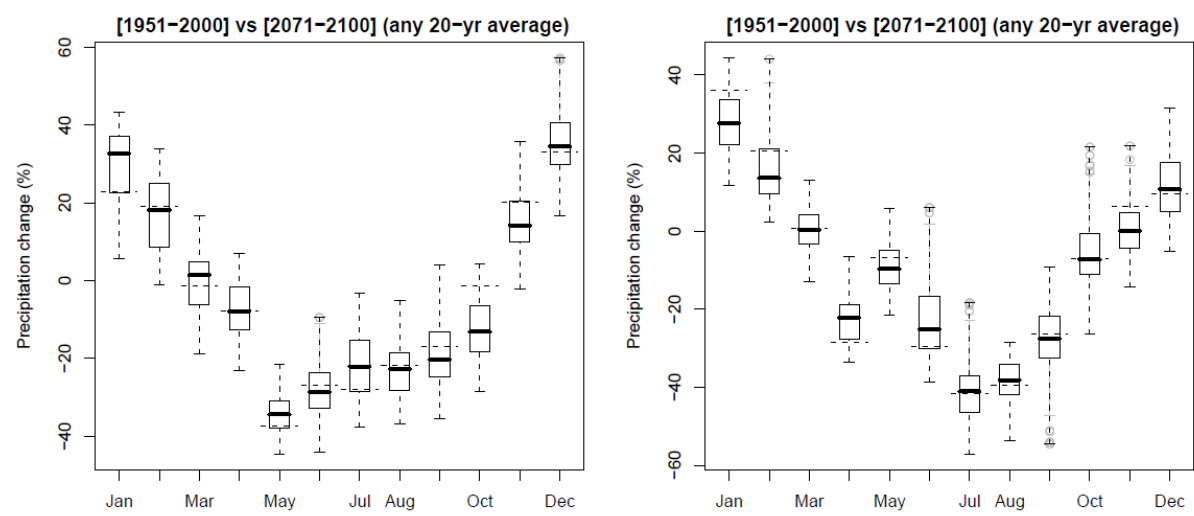

ECHOG - 2080s changes - SRA2

CSMK3 - 2080s changes - SRA2
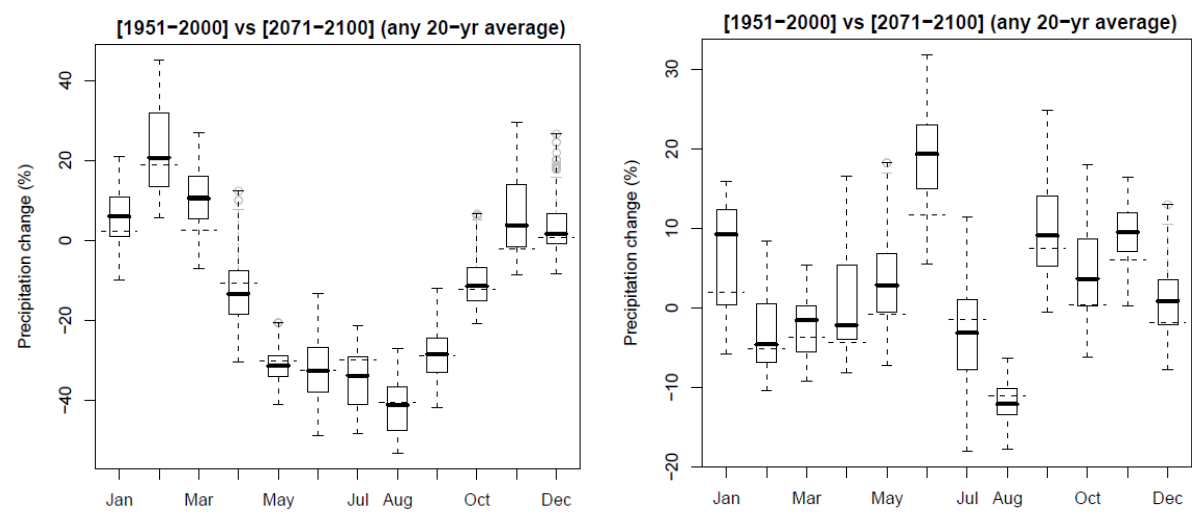
Figure 3. As in Figure 2 but for temperature changes $\left({ }^{\circ} \mathrm{C}\right)$.

MPEH5 - 2080s changes - SRA2

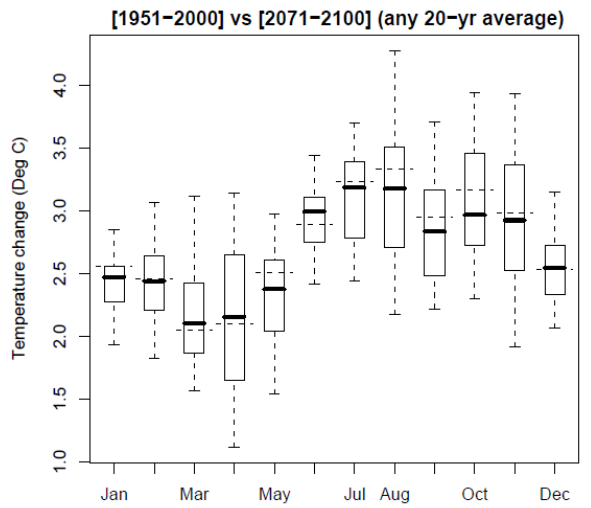

ECHOG - 2080s changes - SRA2

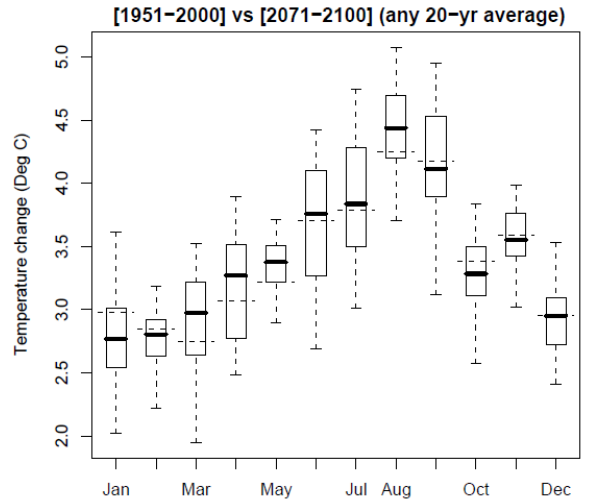

HADGEM - 2080s changes - SRA2

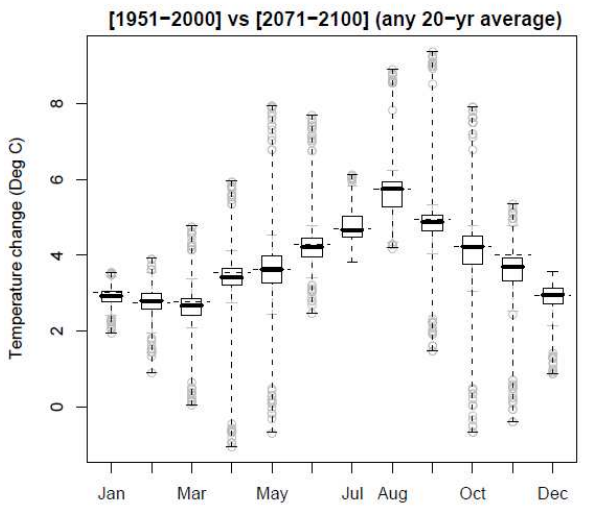

CSMK3 - 2080s changes - SRA2

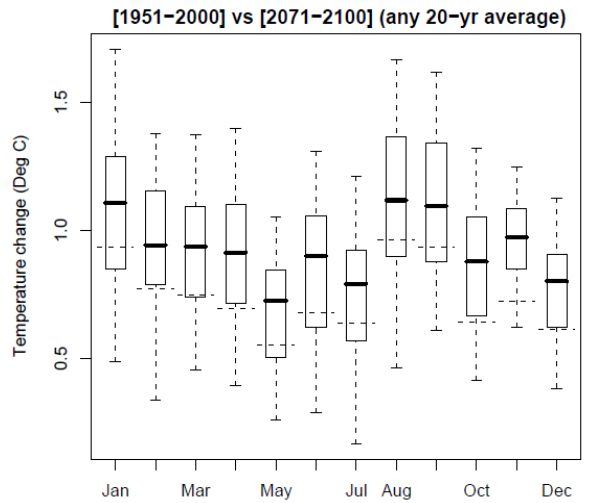


Figure 4. As in Figure 2 but with a harmonic function fitted to CFs for precipitation. The dashed line shows the monthly means based on conventional CF estimation (i.e., a single pair of values indicative of the present and future time slices).
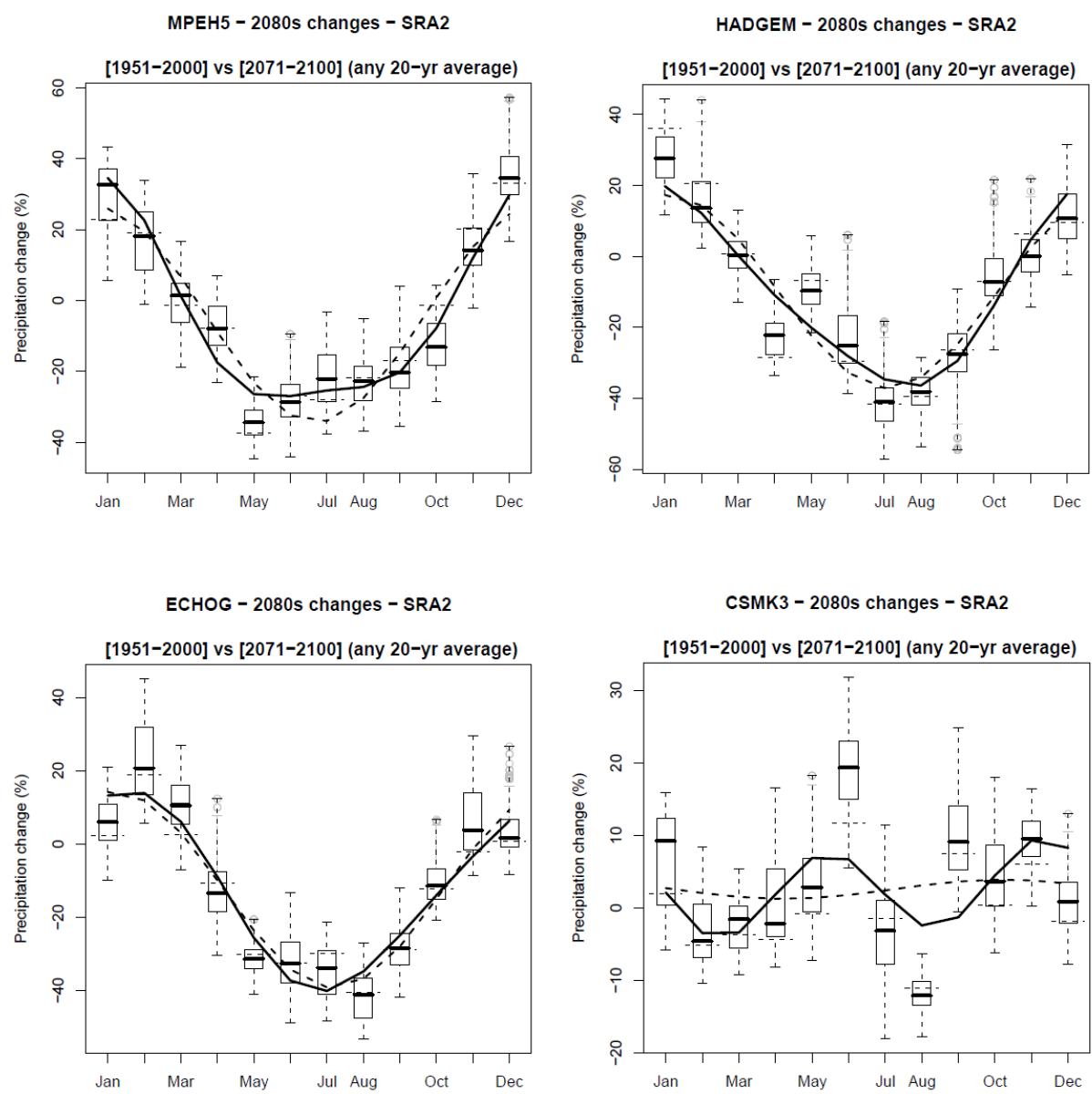
Figure 5. As in Figure 3 but for temperature changes $\left({ }^{\circ} \mathrm{C}\right)$

MPEH5 - 2080s changes - SRA2

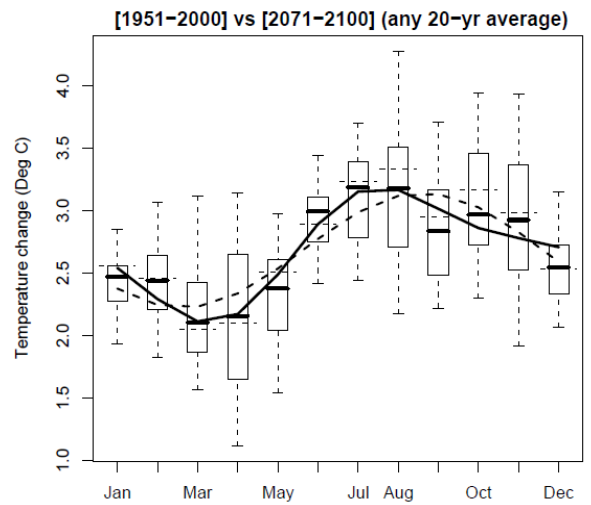

ECHOG - 2080s changes - SRA2

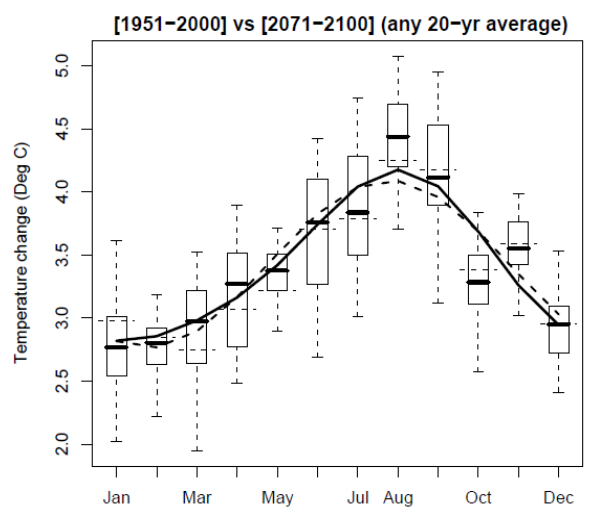

HADGEM - 2080s changes - SRA2

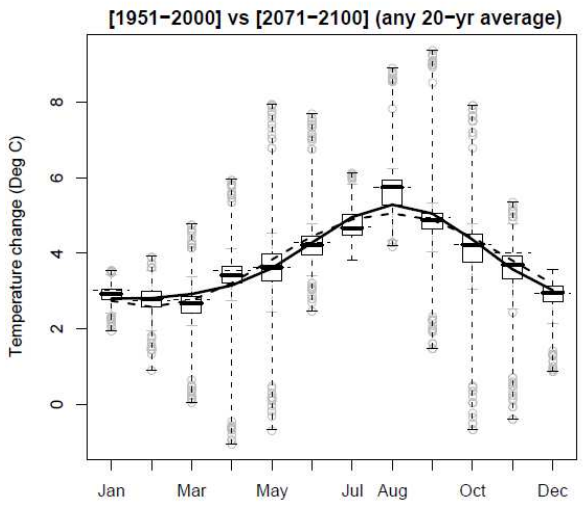

CSMK3 - 2080s changes - SRA2

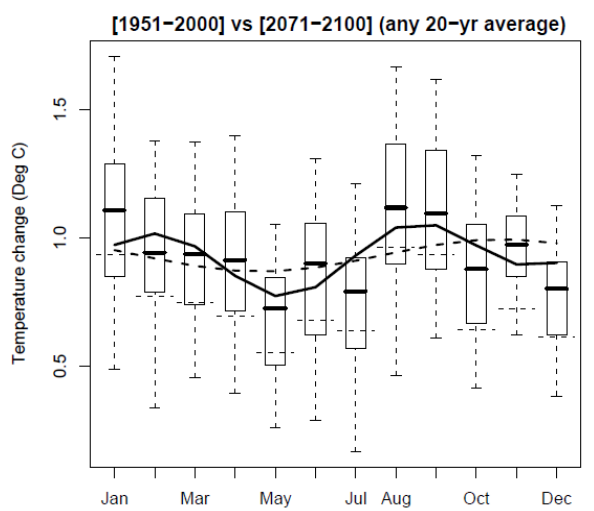


Figure 6. Histograms of the parameters of the harmonic function fitted to CFs for precipitation from all available IPCC-AR4 GCM experiments in the Scotland (left) and SE England (right) grid boxes. Black: SRA1B; White: SRA2; Hashed: SRB1. Mean annual change (in $\%, X_{0}$ top row), maximum seasonal variation (in \%, semiamplitude of first harmonic $A_{1}$ second row) season of maximum change (phase of the first harmonic $\Phi_{1}$ third row); second order seasonal variation (in \%, semi-amplitude of second harmonic $A_{2}$ fourth row) and season of second order maximum change (phase of the second harmonic $\Phi_{2}$ bottom row).
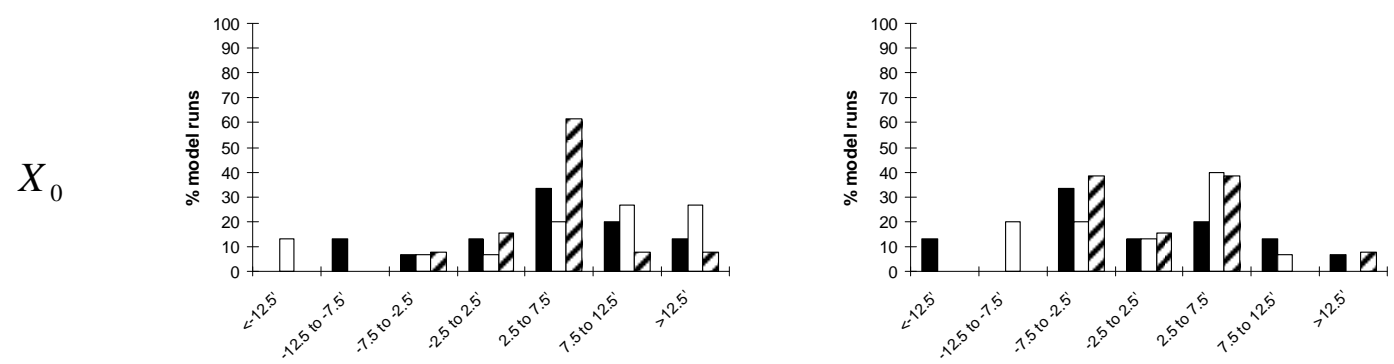

$A_{1}$
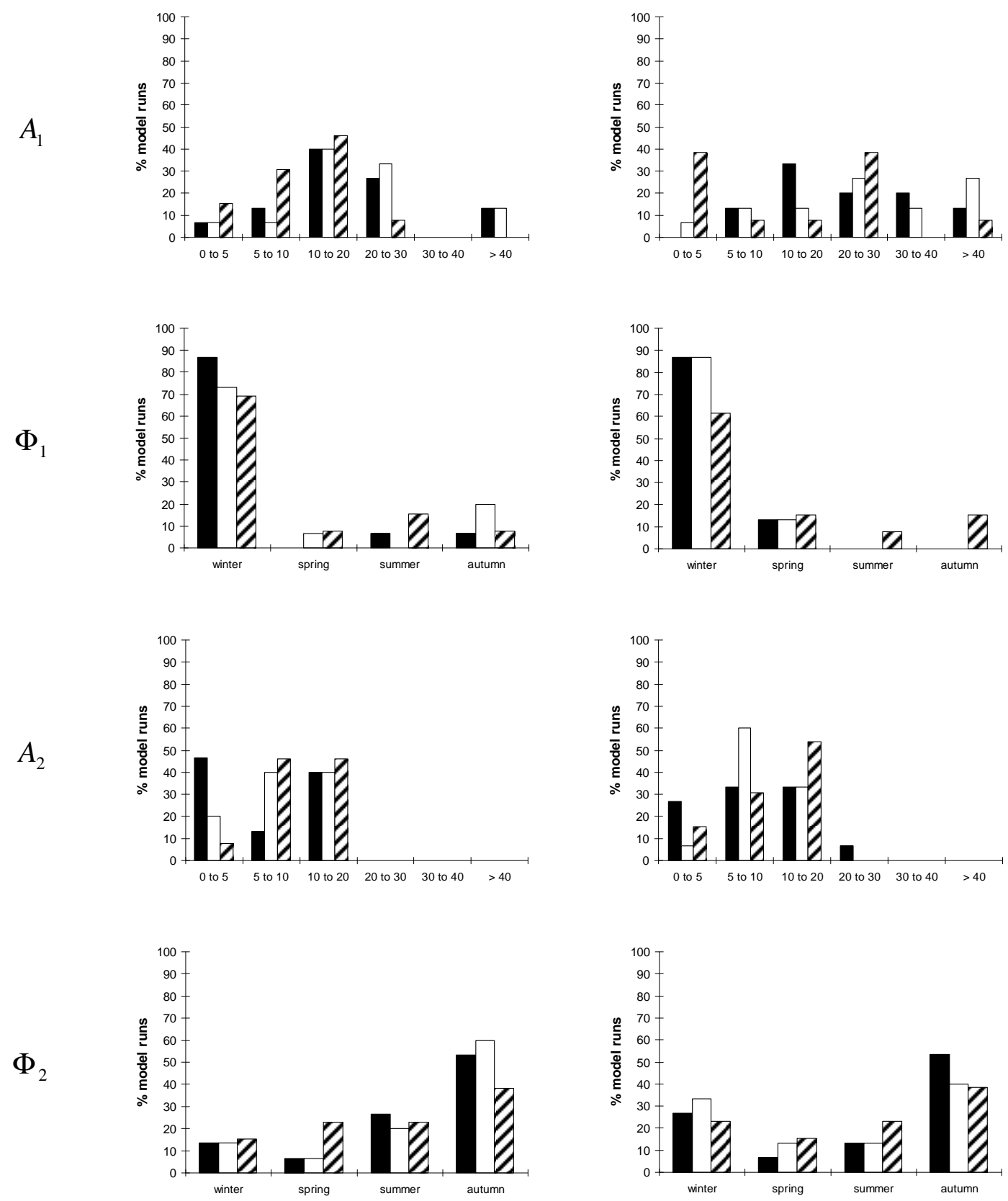
Figure 7. As in Figure 6 but for temperature changes $\left({ }^{\circ} \mathrm{C}\right)$
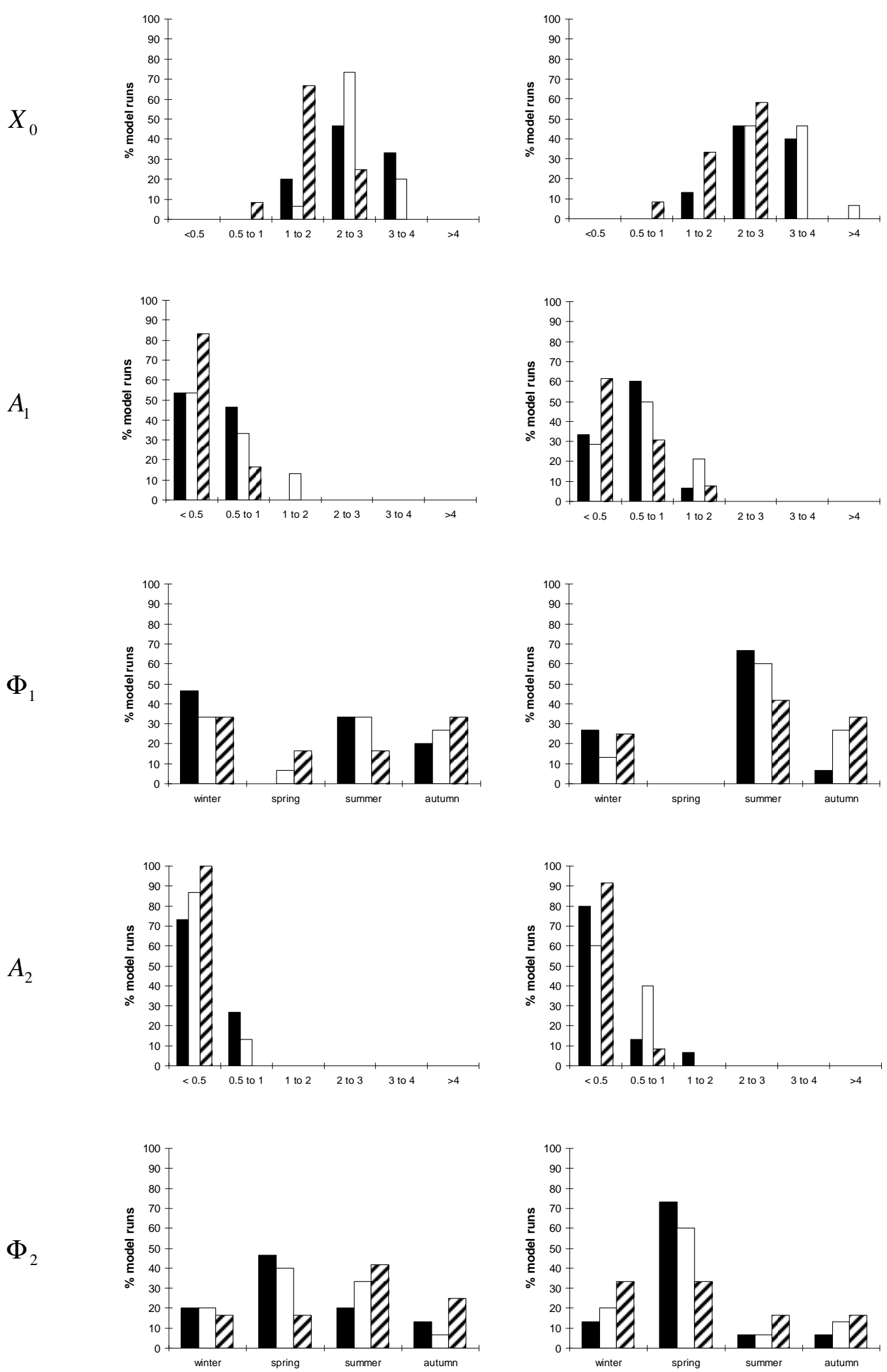
Figure 8. Example response surfaces showing percentage changes in flood peak (using coloured squares) against percentage changes in mean annual precipitation ( $y$-axis) and seasonal variation in the changes (x-axis). The examples are for RP20 for the MediumAugust temperature scenario for the Enrick at Mille of Tore (NE Scotland, left) and Roding at Redbridge (SE England, right). The dots show the distribution of changes inferred from the multi-model, multi-emission ensemble by the 2080s, comprising change factors from IPCCAR4 GCMs (black dots) and UKCP09 RCMs (blue dots).
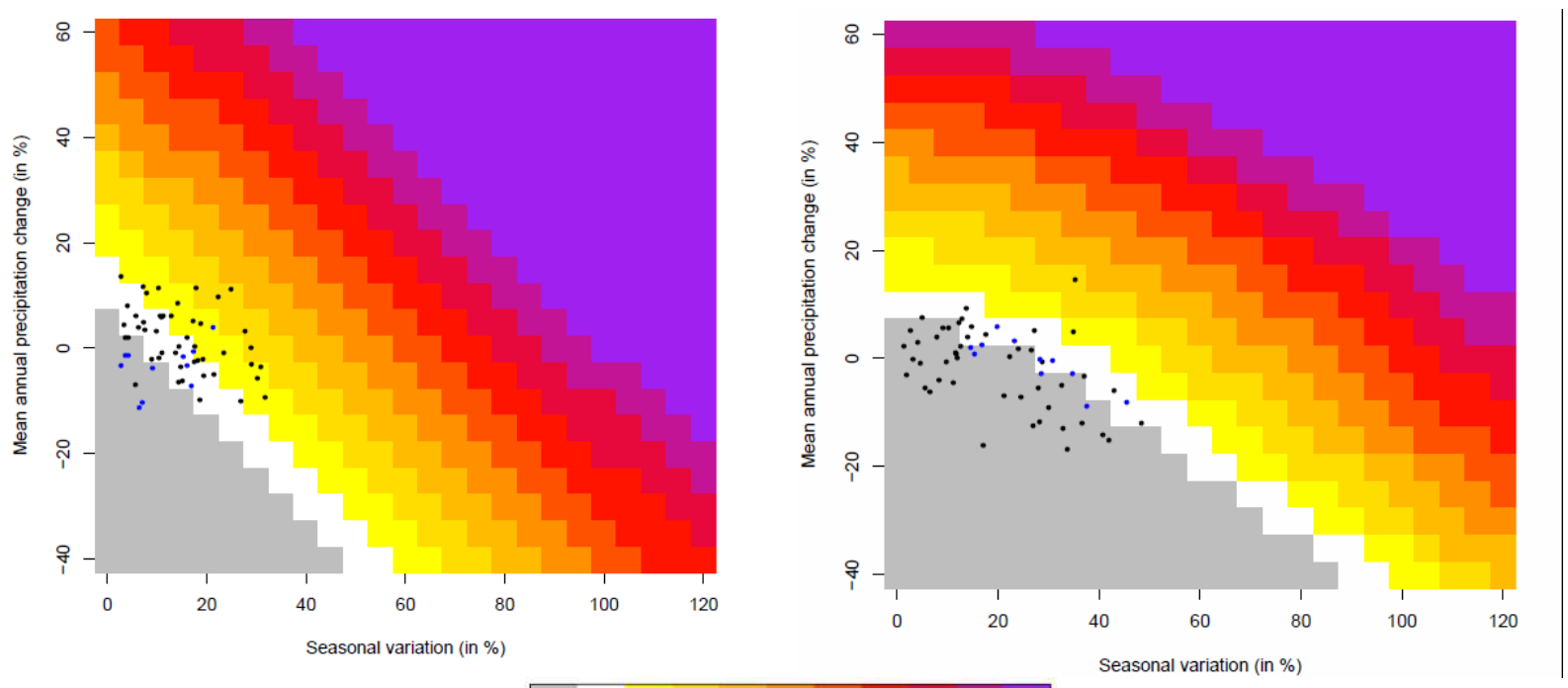

$\begin{array}{llllllllllllll}0 \% & 10 \% & 20 \% & 30 \% & 40 \% & 50 \% & 60 \% & 70 \% & 80 \% & 90 \%\end{array}$ 